\title{
Redaksioneel
}

\section{Die SA Tydskrif vir Natuurwetenskap en Tegnologie vorentoe}

Afrikaans as taal in Suider-A rrika beleel tans 'n ongewing wat oor die afgelope vyf jaar baic verander het - in baic opsigte selfs radikaal verander het. Dic internasionale stroomversnelling waarvan ons deel geword het, het op hierdie wyse nie net gevolge vir Afrikaans as 'n vaktaal nic, maar ook vir dic Tydskrif. Dit is vir die Redaksic egter duidelik dat daar nie net bedreigings is nic, maar ook besondere gelecnthede. Vir 'n besinning is dit goed om van albei 'n lys te malak. As van die belangrikste bedreigings geld:

- Engels is by uitstek dic internasionale kommunikasictaal.

- Daar is 'n apatiese houding oor A frikaans as vaktaal by baic van dic Afrikalanstaliges wat vakkundig akticf is.

- Daar is 'n gebrek aan begrip vir die verskil uussen 'n welenskaplike "lecltaal" en 'n "kommunikasictaal".

Daar is egter unicke geleenthede, soos

- Afrikaans is nie 'n klein, geisolecrde taal nic, maar lid van die veel groter Dietse taalgroep.

- Afrikaans is 'n moderne en terminologies uiters aanpasbarc taal.

- Afrikaans kan steun op 'n baic groot groep vakkundigaklicwe mense.

Om die bedreigings dic hoof te bied en van die geleenthede gebruik te make, moct dic Tydskrif in sy benadering 'n totale openheid vir die hele spektrum van werk binne dic natuurwetenskap en legnick in Afrikaans toon. As 'n cersic slap het daar reeds nuwe publikasicrubrieke die lig gesien en gaan hierdie iendens in die Tydskrif as volg voontgesit word:

- Stanupunte gaan die openheid bevestig en uitbou.

- Opsommings van verhandelings en proefskrific in dic natuurwetenskap en tegniese wetenskap aan universiteite en tegnikons moet bekendheid verleen aan dic navorsingswerk waaraan die nuwe gencrasie van wetenskappers in Alrikaans werk.

- Deurlopende oorsigartikels moet senior Afrikaanstalige voorgraadse en Alrikaanstalige nagraadse studente as leserskring trek, asook die breër leserspublick van die Tydskrif inlig.

- Opsommings/oorsigtc van aktiwitcitc in navorsing en onderrig van A lrikaanstalige departemente alan universiteite en tegnikons word aangevra om bekendheid aan hierdie werk te gec.

- Interessante artikels van algemene belang bime die natuurwetenskap en legnick word verwelkom ten einde die oopslaan van dic tydskrif deur die leser ook steeds 'n prikkelende ervaring te maak.

Vansellisprekend moet dic Tydskril ook die publikasiemedium bly vir uitnemende navorsing in A rrikans. Dit is nie net ononderhandelbatr nic, maar ook noodsaaklik. Die aantreklikheid van die geheel word immers bevestig deur wat bo-aan vonkel. Hierby is die vraag nic die retoriese een of daar in Engels of in Afrikaans gepubliseer moct word nic. Die vratag is hockom daar nie in Engels én Afrikaans gepublisecr moel word nic.

Dic Redaksie kyk deurlopend krities na idees soos dic bogenoemde, en maak ook graag deurlopend sinvolle aanpassings. Wenke en idees uit die leserskring van die Tydskrif is nic net te verwelkom nie, maar sal in hicrdic proses 'n groot hulp wees.

Daan van Wyk

Redaksievoorsitter 